\title{
Echovirus Epidemics, Autoimmunity, and Type 1 Diabetes
}

\author{
Oscar Diaz-Horta1,3, Luis Sarmiento2, Andreina Baj3, \\ Eduardo Cabrera-Rode ${ }^{1}$ and Antonio Toniolo ${ }^{3}$ \\ ${ }^{1}$ National Institute of Endocrinology, Havana \\ 2"Pedro Kouri" Tropical Medicine Institute, Havana \\ ${ }^{3}$ University of Insubria, Varese \\ ${ }^{1,2} \mathrm{Cuba}$ \\ ${ }^{3}$ Italy
}

\section{Introduction}

Type 1 diabetes mellitus [T1D] results from the autoimmune destruction of insulinproducing beta cells triggered by environmental factors (Hyoty \& Taylor, 2002; Jun \& Yoon, 2003). Genetic predisposition accounts for $36-50 \%$ of disease susceptibility as demonstrated in monozygotic twin studies (Barnett et al., 1981; Hemminki et al., 2010; Redondo et al., 2001). Differences in the incidence of T1D among countries are thought to be due to the proportions of HLA susceptibility haplotypes; however, other genes seem to be involved in conferring risk. On the other hand, the bulk of new T1D cases lack family history of the disease, altogether indicating that the contribution of exogenous factors to disease pathogenesis is important. Among examined environmental agents, human enteroviruses (HEVs) seem to play a prominent role (Hyoty \& Taylor, 2002).

HEVs are common RNA viruses spreading through the fecal-oral route. The genus comprises over 100 different virus types (Simmonds, 2006). The positive sense single-stranded $7.5 \mathrm{~kb}$ RNA genome contains a single open reading frame flanked by two untranslated regions (termed 5 and 3' UTRs). A translated single poly-protein is cleaved generating four structural proteins (VP1, VP2, VP3 to VP4) and seven nonstructural proteins $(2 \mathrm{~A}, 2 \mathrm{~B}, 2 \mathrm{C}$ and $3 \mathrm{~A}, 3 \mathrm{~B}, 3 \mathrm{C}$, 3D). VP1 to VP4 proteins form the viral capsid comprising epitopes involved in virus neutralization; they are responsible for the type-specific protective immunity. Nonstructural proteins determine virus replication and cellular pathology (Agol, 2006).

Although prediction of T1D using genetic, immunologic, and biochemical markers is rather accurate (Hirai et al., 2008; Notkins, 2007), the cost-benefit ratio of periodical determinations appears not to justify large scale screening programs. Unfortunately, primary, secondary and tertiary prevention strategies evaluated so far have failed to prevent or halt the initiation or progression of the disease. For instance, attempts to induce disease regression by utilizing either immunosuppressive and/or cell replacement therapies have been successful only temporarily (Shapiro et al., 2006; Voltarelli et al., 2007).

A vaccine inducing neutralization of putative pathogenic HEVs may represent an ideal primary prevention means for T1D. Unfortunately, available data on sequence of HEV isolated from pancreases of patients who died at T1D onset are not sufficient to define the 
characteristics of diabetogenic viruses. Nucleic acid technology has shown HEV genomes in sera, plasma or peripheral blood mononuclear cells of patients with T1D at clinical onset (Yeung et al., 2011). However, complete or partial virus genotyping has not been possible so far. Over the years, indirect evidence indicated that HEVs infections are associated with islet autoimmunity and the development of T1D.

Since 1986, public health surveillance strategies have identified 3 meningitis epidemics in Cuba that were caused by echovirus type $-4,-16$, and -30 . Cases of HEV infections were related to the appearance of autoantibodies towards pancreatic islet cells, the immunological hallmark of T1D. Infection-associated autoantibodies showed subtle differences among these epidemics in terms of titer and antigen specificity. In the epidemic of 1998, higher frequencies of neutralizing antibodies against echovirus 4 were found in T1D patients at onset as compared to controls. In the epidemic of 2006, molecular methods allowed detecting HEV RNA more frequently in T1D patients at onset than in non-diabetic controls. Finally, a case of T1D onset in strict association with a HEV infection was also reported.

Molecular homology between beta cell antigens and HEV proteins has been suggested to explain the participation of HEV in T1D pathogenesis. Indeed, we have shown that inoculation of rabbits with selected HEV types caused the appearance of GAD65 antibodies, an early marker of disease progression.

In this chapter, we provide epidemiological and experimental data indicating HEV as possible agents involved in islet cell associated autoimmunity and T1D. The genetic characteristics of the Cuban admixed population influencing T1D genetic susceptibility, the high HEV circulation and low T1D incidence paradox, and how the HEV-disease associations in the Cuban population is inserted into the worldwide landscape will be discussed.

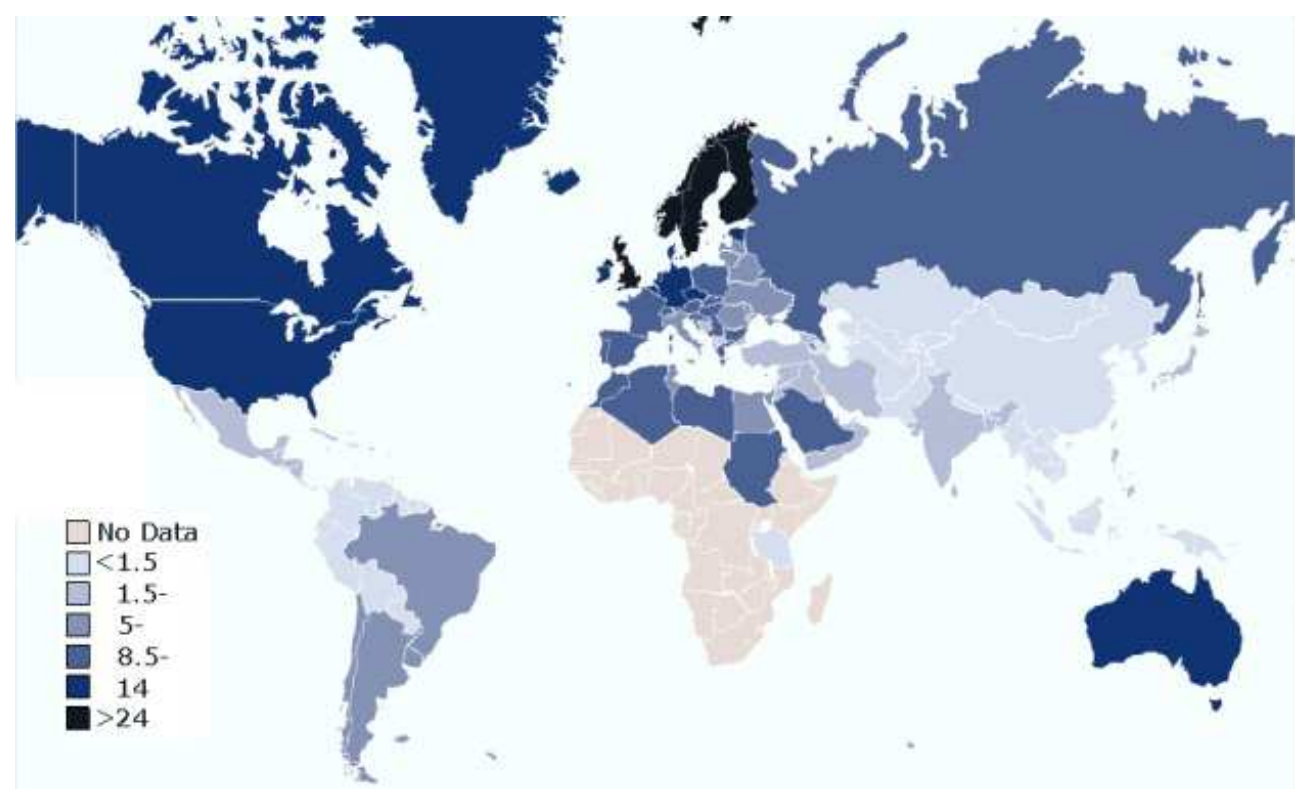

Fig. 1. Worldwide incidence of type 1 diabetes in children under 14 years of age. Incidence is given per 100,000 inhabitants per year (http:/ /www.diabetesatlas.org/map). 


\section{Population genetic background influences T1D incidence}

The incidence of T1D varies widely across nations [Figure 1]. In the year 2009, Nordic countries and UK appeared to show the highest rates [>24/100,000 per year], whereas other European and North-American countries show high to moderate rates [8.5-24/100,000 per year]. Latin-America and Asia exhibit the lowest incidence [usually $<8.5 / 100,000$ per year]. Worldwide variations of T1D incidence appear to derive from differences in genetic and/or environmental factors. Within the genetic component, the proportion of susceptibility/protection HLA haplotypes appears to have the highest influence (Concannon et al., 2009). In the late '80s, the presence of a non-aspartic aminoacid in the position 57 of the DQ beta chain (Morel et al., 1988) was proposed to be the most sensitive marker to assess T1D risk. Then, the frequency of this marker appeared to be strongly related with the incidence of T1D across studied populations (Dorman et al., 1990). However, subsequent studies including more populations showed that the accuracy of the marker was not as good as expected (Dorman \& Bunker, 2000).

The peak of association between T1D and a gene has been shown to be $85 \mathrm{~kb}$ centromeric of HLA-DQB1 (Herr et al., 2000). However, the DR locus seems to confer risk to T1D per se (Fernando et al., 2008), not just as a result of linkage disequilibrium with DQ. In fact, effects of individual DR and DQ alleles on disease risk are modified by the haplotypes on which they are carried (She, 1996). Interestingly, a very accurate predictor of T1D susceptibility consists of the present of polar residues at beta 7 and beta 37 in both DR/DQ chains, representing an additional factor for disease progression the absence of aspartic acid at DQ beta 57 (Parry \& Brooks, 2008).

Not all populations display the same HLA DR/DQ as T1D susceptibility haplotypes. For instance, considering two-locus haplotypes, DRB1*0301-DQB1*0201 and DRB1*0401DQB1*0302 are positively associated with T1D in European populations, whereas DRB1*0405DQB1*0401 and DRB1*0901-DQB1*0303 haplotypes are associated with the disease in most East Asian populations (Ikegami et al., 2008). In populations of European origin, the threelocus haplotypes DRB1*04-DQA1*0301-DQB1*0302 and DRB1*03-DQA1*0501-DQB1*0201 have been shown to play a predominant role in conferring disease susceptibility (Fernando et al., 2008) being heterozygosity for both haplotypes the greatest known genetic risk for T1D. For the Cuban population, these haplotypes are also represented in subjects with T1D and they display odds ratios of 26 and 7.6, respectively (Diaz-Horta et al., 2010). On the other hand, DRB1*1501-DQA1*0102-DQB1*0602 is the haplotype conferring the highest protection for T1D in both European and Cuban populations. This is in agreement with the genetic structure of the Cuban population (Cintado et al., 2009) which is composed mainly by individuals with Spanish descent $(65.05 \%)$ followed by individuals with a variable degree of Spanish and West African admixed ancestry (23.84\%) (http://en.wikipedia.org/wiki/Cubans). In a collaborative study, the frequency of HLA alleles in a sample of the healthy Cuban population was analyzed (Alegre et al., 2007). A neighbor-joining tree using HLA-DRB1 alleles showed that the Cuban population is grouped together with Mediterranean populations and well separated from Amerindian and Oriental populations. Similarly, genetic distances (based on HLA-DRB1DQB1 allelic frequencies) between Cubans and other populations show that Cubans are close to Mediterranean and European populations. French, Berbers and Spaniards show the closest genetic distances to Cubans, followed by Russians, Algerians and Spanish Basques (Alegre et al., 2007).

It is important to notice that associations between genotype and outcome (e.g. T1D in the present analysis) may be confounded by unrecognized population stratification. In Cuba, 
population stratification exists because the population has been formed by admixture between subpopulations (mainly Spanish and West Africans) and admixture proportions (defined as the proportions of the genome that have ancestry from each subpopulation) vary between individuals (Hoggart et al., 2003). By utilizing ancestry informative markers, T1DHLA associations were controlled for factors attributable to admixture or stratification of the population (Diaz-Horta et al., 2010). After controlling for individual admixture, HLA alleleand haplotype-T1D associations mentioned above remained significant indicating their consistence.

Altogether, these studies indicate that the large differences in incidence of T1D between the Cuban and the European population is difficult to explain on the basis of HLA alleles or haplotypes alone.

The HLA region is not the sole genetic factor associated with T1D. Other genes, many of them involved in the regulation of the immune response (e.g., expansion of self-reactive cells, regulation of immune functions, interference with immune regulation) and the betacell survival, contribute to disease risk (Liston, 2010). For instance, insulin has been suggested to be the first autoantigen to which the immune tolerance is lost (Nakayama et al., 2005). Coincidentally, the second highest odds ratio for a genetic marker after the HLA region is a variable nucleotide tandem repeat (VNTR) minisatellite located at the 50 end of the insulin gene. More recently, a polymorphism [IFIH1] of a gene encoding for a cytoplasmic helicase that mediates the induction of the interferon response to viral RNA (Nejentsev et al., 2009) has been linked to T1D. This particular association represents genetic evidence suggesting the participation of RNA viruses in the etiology of T1D.

Ethnicity has also been proposed to influence T1D incidence (Karvonen et al., 2000). Perhaps, one of the most illustrative examples of this phenomenon is the large difference of T1D incidence among the 3 principal ethnic groups living in the USA: European descendants, African Americans and American natives (Borchers et al., 2010). Other epidemiological study suggested that differences in T1D incidence among countries of Latin America could be explained by the proportion of the Amerindian population in those countries (Collado-Mesa et al., 2004). Using ancestry informative markers, we have recently shown that ancestral proportions do influence T1D development (Diaz-Horta et al., 2010). Studies of this type allow evaluating the influence of genetic background in disease incidence considering a homogeneous distribution of environmental factors across a given admixed population. In Cuba, individuals carrying high European ancestry proportions in their genome seem to be more prone to develop the disease than those with high African ancestry (figure 2). The size of this effect was estimated as 5.7 odds ratio (95\% CI 1.2-36). This value embodies the odds ratio for T1D associated with a unit change in European admixture proportion (from 0 to 1 ).

Overall, these data indicate that genetic background does influence T1D risk/protection. However, the involved genetic determinants are not restricted to HLA alleles or haplotypes alone.

More recently, using a novel genomic analysis, it has been discovered that the genetic evidence linking virus infections and T1D is not limited to the IFIH1 polymorphism (Heinig et al., 2010). Indeed, it seems that an entire network of interferon response genes driven by the transcription factor IRF7 is associated with T1D. Taking in consideration that HEV infections are relatively frequent and that the latter genetic finding associates a robust antiviral response with T1D susceptibility, it is likely that the host response to certain virus infections is more pathogenic than the virus itself (Foxman \& Iwasaki, 2011). 


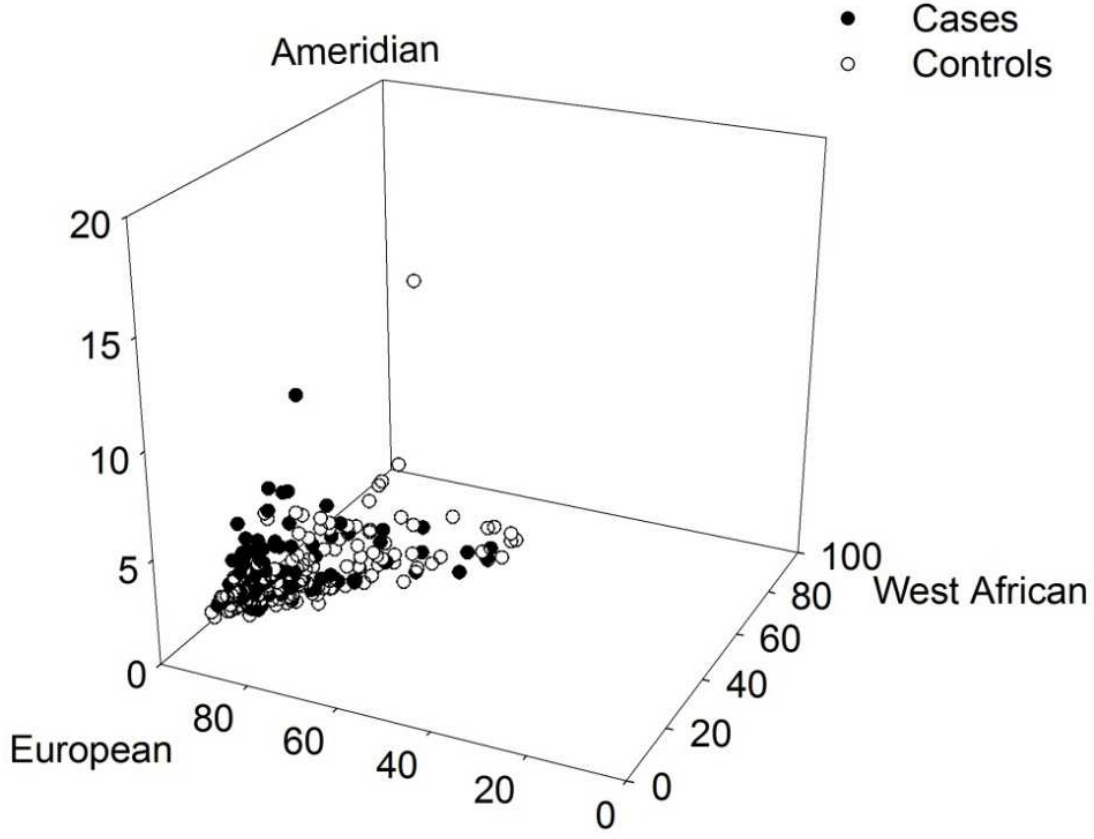

Fig. 2. Distribution of individual admixture estimates in 100 T1D cases and 129 matched non-diabetic subjects in a sample of the Cuban population (Diaz-Horta et al., 2010). Each of the three founder populations constitutes the axes of the graph. Each symbol represents a single subject and its position is determined by the ancestry proportions.

\section{Environmental factors and T1D incidence}

The finest epidemiological evidence indicating the large contribution of environmental factors in the pathogenesis of T1D is the pairwise T1D discordance of $>60 \%$ among monozygotic twins (Knip et al., 2005; Redondo et al., 1999). Other studies of populations migrating to nations with dissimilar T1D incidences than that of their origins (Akerblom \& Knip, 1998) are adequate examples, since they minimize the variability of genetic background. In addition, the constant and rapid increase of T1D incidence rates worldwide cannot be explained by changes in the genetic background of any particular populations.

A host of variants have been associated with T1D incidence and termed "environmental factors". Among them: geographic latitude, sun exposure, mean temperature, breast feeding rates, cow's milk consumption, national prosperity (infant mortality rate, life expectancy at birth, and national human development index), urban-rural status (Borchers et al., 2010). These and other associations, sometimes discrepant (Borchers et al., 2010), are obviously the reflection of underlying molecular events. Most of these events are unknown but some has been extensively discussed in previous reviews (Cooke, 2009; Feillet \& Bach, 2004; von Herrath, 2009). A variety of associations with viruses have been reported for human T1D, including rubella, mumps, and cytomegalovirus infections. However, among investigated agents, HEVs appear to play a prominent role (Hyoty \& Taylor, 2002). 
The role of the adaptive immune system in triggering or protecting against virus-induced autoimmunity was addressed in a pioneer study of Notkins and Yoon (Notkins \& Yoon, 1982). Two strains of encephalomyocarditis (EMC) virus were used to inoculate genetically susceptible mice: a diabetogenic (D) variant of the EMC virus and a non-diabetogenic (B) variant. Both derived from plaque purification of an $\mathrm{M}$ variant of the virus capable to induce a diabetes-like syndrome in susceptible mice. Note that EMC virus belongs to the picornavirus family and is classified as an animal cardiovirus. Interestingly, the two variants were antigenically indistinguishable but genome sequence analysis revealed 14 nucleotide differences between them (Bae et al., 1989). In a subsequent study, the analysis of several mutant viruses generated from the EMC-B and EMC-D variants, revealed that just one amino acid at position 776 (alanine) was responsible of the diabetogenic effects (Bae \& Yoon, 1993). Finally, it was shown that protection for T1D was achieved in an antigen-dependent fashion by injection of the non-diabetogenic EMC-B variant prior to the inoculation of EMCD diabetogenic variant.

Although certain pathogens (e.g. putative diabetogenic HEVs) may initiate or accelerate autoimmunity and T1D, it is also likely that exposure to common or non diabetogenic pathogens may protect against this process. For example, over the last fifty years (1950 to 2000), the decreasing incidence of prototypical infectious diseases such as hepatitis A, measles, mumps, rheumatic fever, tuberculosis has been linked to the increasing incidence of immune-mediated disorders (e.g., asthma, multiple sclerosis, Crohn's disease) (Bach, 2002). In addition, recognized HEV infections appear to be an infrequent event in countries exhibiting an elevated incidence of T1D (Viskari et al., 2005). In a study, authors measured the frequency of neutralizing antibodies $(\mathrm{NtAb})$ against selected HEV types in pregnant women (mean age 25-30 years) from populations of high and low-intermediate incidence of $\mathrm{T1D}$. The frequency of NtAb (titer $\geq 4$ ) in the high T1D incidence country (Finland) was 40.5 - $65.0 \%$ (minimum - maximun) for single NtAbs against different HEVs and $38.5 \%$ for multiple NtAbs. In contrast, in the adjacent regions Estonia and Karelia which are characterized by low T1D incidence, the values were $71.9-90.6 \%$ and $84.2 \%$, respectively. Interestingly, the frequencies of NtAbs (especially those against CA9, CB4 and CB5) in pregnant women from Estonia and Karelia (85.7, 71.9 and $90.6 \%$, respectively) are similar to

\begin{tabular}{|c|c|c|c|c|c|c|c|c|c|c|c|c|c|c|}
\hline \multirow{2}{*}{$\begin{array}{l}\text { के } \\
\stackrel{5}{0} \\
0 \\
0\end{array}$} & \multirow[t]{2}{*}{$\mathrm{N}$} & \multirow{2}{*}{$\begin{array}{l}\text { Age } \\
\text { Mean }\end{array}$} & \multirow{2}{*}{$\begin{array}{c}\text { Sex } \\
\%(\mathrm{M})\end{array}$} & \multicolumn{7}{|c|}{ Coxsackievirus (\%) } & \multicolumn{4}{|c|}{ Echovirus (\%) } \\
\hline & & & & CA9 & CB1 & CB2 & CB3 & CB4 & CB5 & CB6 & E4 & E6 & E9 & E11 \\
\hline 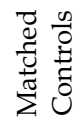 & 57 & 8.3 & 56.1 & 78.9 & 57.9 & 64.9 & 77.2 & 82.5 & 21.1 & 1.8 & 1.8 & 57.9 & 54.4 & 54.4 \\
\hline 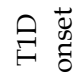 & 33 & 10.7 & 45.5 & 93.9 & 57.6 & 72.2 & 60.6 & 93.9 & 33.3 & 6.1 & 21.2 * & 66.7 & 72.7 & 57.6 \\
\hline
\end{tabular}

Table 1. Frequency of HEV neutralizing antibodies in Cuban subjects at the clinical onset of T1D and nondiabetic subjects matched for age, sex, date of collection and location (DiazHorta et al., 2001). * $\mathrm{p}<0.05$, Fisher's exact test. 
those found in 7-11 year-old nondiabetic children from Cuba (78.9, 82.5 and $21.1 \%$, respectively) (Diaz-Horta et al., 2001). These data indicate that the circulation of enteroviruses is very high in both regions. It is also well known that the frequency of NtAbs against HEVs largely depends on the age of subjects, being much higher at older ages. This supports the hypothesis that the more a population is exposed to common HEV types the higher is its protection against subsequent exposure to diabetogenic HEVs.

In animal models of spontaneous T1D (i.e., the NOD mouse and the BB rat) it has been demonstrated that the incidence of the disease is much higher in those animals bred in specific pathogen-free environments than in conventional conditions (Bach, 2002). By just decontaminating the food in the latter conditions an increase in incidence was observed. More interesting, prevention of T1D in NOD mice has been achieved by treatment with a variety of immune enhancers, including complete Freund's adjuvant (McInerney et al., 1991), immunogenic but not tolerated peptides (Vaysburd et al., 1995), Mycobacterium avium (Martins \& Aguas, 1996), Lactobacillus casei (Matsuzaki et al., 1997), Mycobacterium leprae (Nomaguchi et al., 2002), lymphocytic choriomeningitis virus (LCMV) (Christen et al., 2004). T1D prevention has also been achieved by exposure to helminthes or products from these organisms, however, it is important to recognize that not all infecting agents, parasites or their products are able to induce this effect (Cooke, 2009). Another important observation is the fact that the timing of exposure to these "protective" agents largely influences the outcome (Cooke, 2009). For example, if the exposure is performed before the appearance of the mononuclear infiltrate in the pancreas of NOD mice (generally around week 5) then protection is generally achieved. After that time, exposure to the protective agent is useless and fails to prevent T1D.

Thus, protection through infection or by stimulation of the immune system has allowed applying the term "hygiene hypothesis" to experiments in animals. The term was originally coined on the basis of epidemiologic studies of poliomyelitis. Several mechanisms have been proposed to explain this phenomenon. For example, a study conducted by von Herrath (von Herrath, 2009) clearly demonstrated that regulatory T-cells (CD4+ CD25+ Tregs) can invigorate by infection in a toll like receptor (TLR)-2 dependent fashion. These cells, instead of exerting effector functions such as killing infected cells or inducing interferon production, can turn off immune responses. The increment in TGF- $\beta$ concentrations induced by the viral infection is associated with Treg invigoration (Aumeunier et al., 2010; von Herrath, 2009). Other cytokines induced simultaneously are the programmed cell death ligand 1 (PD-1L) and the tumor necrosis factor (TNF)- $\alpha$ which in turn may mediate the bystander death of auto-aggressive T-cells. The protective effect of viral infections and other immune modulators has also been associated with the induction of interferon gamma-induced protein $10 \mathrm{kDa}$ (IP-10) and other pro-inflammatory cytokines (Christen et al., 2004).

Taken together, these data suggest that not only the adaptive immune response provides protection against exposure to diabetogenic viruses, but also the innate immune system. Multiple non-specific stimuli acting on the immune system during early childhood and before puberty are hoped to provide an effective strategy to reduce the increasing incidence of T1D (Petrovsky, 2010).

\section{Classification of enteroviruses and properties of the echovirus group}

HEVs are extremely common RNA viruses that spread mainly through the fecal-oral route. They are etiological agents of different clinical entities varying from asymptomatic to mild, 
severe, or fatal diseases. Overall, these agents cause millions new infections per year in the US (Khetsuriani et al., 2006). The enterovirus genus comprises over 100 antigenically different virus types (Simmonds, 2006). The single-stranded 7.5 kb RNA genome (figure 3) is positive sense and contains a single open reading frame flanked by two untranslated regions (5 and 3' UTRs). The coding region is translated into a single polyprotein (of approximately 2,200 amino acids) which is cleaved to generate four structural proteins (VP1 to VP4) and seven nonstructural proteins (2A to $2 \mathrm{C}$ and $3 \mathrm{~A}$ to $3 \mathrm{D}$ ). VP1-VP4 proteins are assembled to form the viral capsid whose external surface comprises the epitopes involved in virus neutralization that are responsible for the type-specific protective immunity. Nonstructural proteins have enzymatic functions and play essential roles in virus replication and cellular pathology. An important property of HEVs (common to all RNA viruses) is their high mutation and recombination rates. RNA replication is extremely error-prone, due to the lack of proofreading activity of the viral RNA-dependent RNA polymerase, taking the error rate to approximately one per genome replication (Savolainen-Kopra \& Blomqvist, 2010).

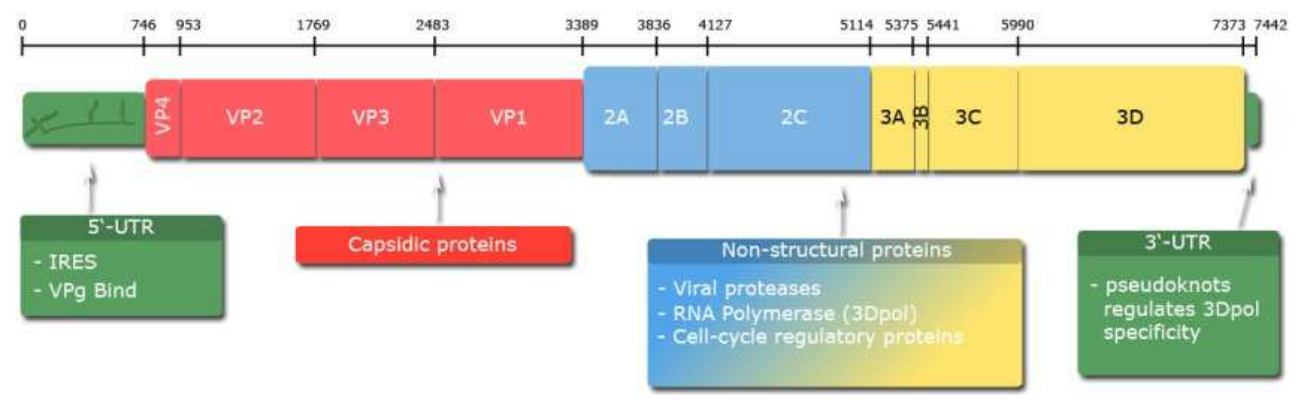

Fig. 3. HEV genome organization.

HEVs were originally classified on the basis of shared pathogenic properties in experimental animals. For example, polioviruses were described to cause a poliomyelitis resembling disease in primates; coxsackieviruses $\mathrm{A}$ and $\mathrm{B}$, produced flaccid and spastic paralysis in newborn mice, respectively; echoviruses were not associated to any known clinical symptom or disease. Echoviruses received their name from the initials of "Enteric isolates", "Cytopathogenic in tissue culture", isolated from "Humans" and, "Orphans" because they were not apparently associated to any disease (Fields et al., 2007). Currently, many HEV types have been fully sequenced allowing their genetic classification. For example, considering the amino acid similarity of the capsid protein region P1 (comprising VP4, VP2, VP3 and VP1 proteins) HEVs are now grouped into species A, B, C and D (table 2).

As observed in table 2, there is some conflict between the classical subgroup division and the genetic classification of HEVs. For instance, although coxsakieviruses B, echoviruses (now within the species B) and polioviruses (species C) are rather genetically homogeneous, coxsackieviruses A distribute in species A, B and C. On the other hand, echoviruses took their name because they were not originally associated to any disease. Now, however, it is known that they are one of the main causes of aseptic meningitis as well as other diseases, and that these agents are widespread in the environment (Djikeng et al., 2009). Interestingly, the genetic subgrouping of enteroviruses is quite consistent regardless the zone of the genome being used for the analysis (Hyypia et al., 1997). 


\begin{tabular}{|c|c|c|}
\hline Species & $\begin{array}{l}\text { Number of } \\
\text { known } \\
\text { serotypes }\end{array}$ & Serotypes \\
\hline A & 17 & $\begin{array}{l}\text { coxsackievirus A2 (CV-A2), CV-A3, CV-A4, CV-A5, CV-A6, } \\
\text { CV-A7, CV-A8, CV-A10, CV-A12, CV-A14, CV-A16, } \\
\text { enterovirus A71 (EV-A71), EV-A76, EV-A89, EV-A90, EV-A91, } \\
\text { EV-114 }\end{array}$ \\
\hline B & 58 & $\begin{array}{l}\text { coxsackievirus B1 (CV-B1), CV-B2, CV-B3, CV-B4, CV-B5, CV- } \\
\text { B6, CV-A9, echovirus } 1 \text { (E-1), E-2, E-3, E-4, E-5, E-6, E-7, E-9, } \\
\text { E-11, E-12, E-13, E-14, E-15, E-16, E-17, E-18, E-19, E-20, E-21, } \\
\text { E-24, E-25, E-26, E-27, E-29, E-30, E-31, E-32, E-33, enterovirus } \\
\text { B69 (EV-B69), EV-B73, EV-B74, EV-B75, EV-B77, EV-B78, EV- } \\
\text { B79, EV-B80, EV-B81, EV-B82, EV-B83, EV-B84, EV-B85, EV- } \\
\text { B86, EV-B87, EV-B88, EV-B93, EV-B97, EV-B98, EV-B100, EV- } \\
\text { B101, EV-B106, EV-B107 }\end{array}$ \\
\hline $\mathrm{C}$ & 20 & $\begin{array}{l}\text { poliovirus (PV) 1, PV-2, PV-3, coxsackievirus A1 (CV-A1), } \\
\text { CV-A11, CV-A13, CV-A17, CV-A19, CV-A20, CV-A21, CV- } \\
\text { A22, CV-A24, enterovirus C95 (EV-C95), EV-C96, EV-C99, } \\
\text { EV-C102, EV-C104, EV-C105, EV-C109 and EV-C113. }\end{array}$ \\
\hline $\mathrm{D}$ & 4 & EV-D68, EV-D70, EV-D94 and EV-D111 \\
\hline
\end{tabular}

Table 2. Classification of human enteroviruses (Adapted from the Picornaviridae database http://www.picornaviridae.com/; Mars 2011).

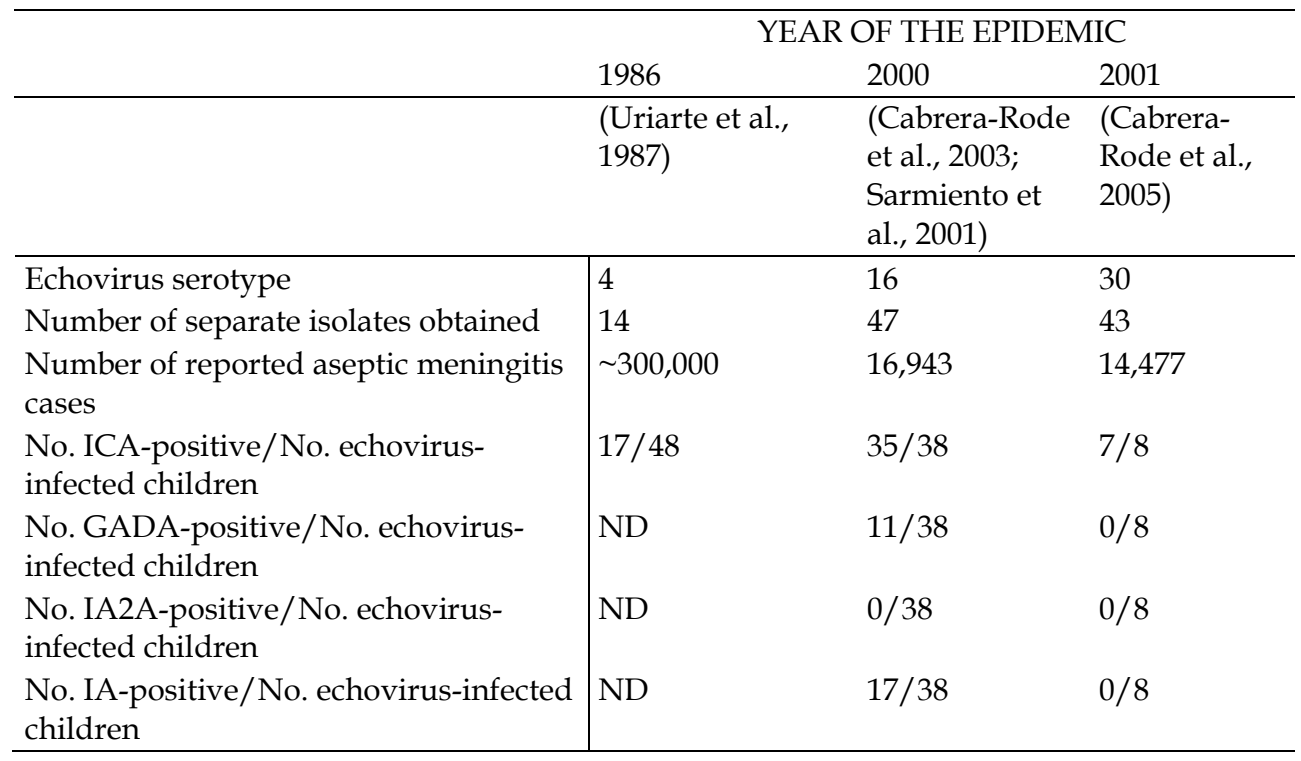

Table 3. Summary of epidemiology and islet associated autoantibodies in echovirus epidemics in Cuba. ND= not done 


\section{Cuban epidemics of aseptic meningitis due to echoviruses}

Since 1986, virus surveillance in Cuba has identified 3 different echoviruses (HEVs B) as the causing agents of 3 epidemics of aseptic meningitis (table 3). The predominant clinical manifestations in all three epidemics were vomiting, headache, and fever. No deaths related to aseptic meningitis were reported and all patients recovered completely. Cerebrospinal fluid (CSF), sera (during acute and convalescent stages of the disease) and feces were utilized for enterovirus detection using a specific RT-PCR technique. For enterovirus identification a neutralization test using the Lim-Benyesh-Melnick (LBM) antisera pools was used. Viral isolation was achieved by inoculating specimens on monolayers of human embryo fibroblasts (PhuE-1) and monkey kidney cells (Vero). Sera from infected children were matched with at least two control sera from healthy children for age, sex, date of collection, and location. All control subjects had no family history of diabetes, were screened for diabetes-associated antibodies (ICA, GADA, IAA, IA2A) and for neutralizing antibodies against different enterovirus serotypes.

The presence of islet cell antibodies (ICA) is considered the immunological hallmark of T1D. One of the most notable observations from these HEV epidemics is that in the convalescent but not in the acute stage of the infection, ICA seroconversion was demonstrated. On the other hand, in the epidemic caused by echovirus 16 we also detected the emergence of IAA, GADA and IA2A (Cabrera-Rode et al., 2003). The islet cell autoimmunity was clearly infection-associated, since no serum samples from uninfected subjects serologically negative for neutralizing antibodies to E16 and E30 had ICA. The seroconversion of T1D islet associated antibodies in subjects does not seem to be a general unspecific antibody response, since all infected subjects were negative for thyroid microsomal or parietal gastric cell autoantibodies. As for the echovirus 30 meningitis, we detected ICA seroconversion in a high percentage of patients but not GADA, IAA or IA2A seroconversion. From this and other studies (table 4), it can be observed that different echovirus types are associated with a variety pancreatic autoantibodies.

\begin{tabular}{|c|c|c|c|c|c|}
\hline ICA & GADA & IA2A & IAA & Serotype & Reference \\
\hline tैe & - & At & - & Echovirus 3 & (Williams et al., 2006) \\
\hline set & ett & - & & Echovirus 6 & (Otonkoski et al., 2000) \\
\hline of & - & - & & Echovirus 9 & (Vreugdenhil et al., 2000) \\
\hline of & ty & fy & & Echovirus 16 & (Cabrera-Rode et al., 2003) \\
\hline क्षै & - & - & - & Echovirus 30 & (Cabrera-Rode et al., 2005) \\
\hline ât & ett & - & - & Non polio HEV & (Lonnrot et al., 2000b) \\
\hline of & - & tyt & ty & Non polio HEV & (Hyoty \& Taylor, 2002) \\
\hline
\end{tabular}

Table 4. Patterns of T1D-associated autoantibodies in the course of echovirus infections. 
During the echovirus 30 epidemic we reported an adolescent who developed pancreatic autoantibodies and T1D after infection (Cabrera-Rode et al., 2005). ICA and IA2A were detected post-infection and; the analysis of neutralizing antibodies to enterovirus serotypes most frequently isolated during the last 30 years in Cuba showed high titers of neutralizing antibodies only for E30 (titer 1:80) suggesting that this virus was the agent causing the aseptic meningitis. Interestingly, the patient carried the HLA DR15/DR7 and DQ2/DQ6 determinants that confer T1D protection.

It is important to notice that in mice inoculated with the echovirus 4 strain circulating during the late ' 80 s in Cuba there was a reduction of the insulin concentration and overall protein synthesis in pancreatic islets (Szopa et al., 1992). Remarkably, Roivainen et al (Roivainen et al., 2002) showed that the capacity of an enterovirus to kill human beta cells or impair their function is not entirely defined by the serotype. For example, the prototype echovirus 30 strain (Bastianni) appear not to produce damage to beta cells while other isolates of echovirus $30 \mathrm{do}$. Similar results were obtained with echovirus 9 (Roivainen et al., 2002). Another interesting observation from echovirus epidemics in Cuba is that the titer of islet-associated autoantibodies correlates with the titer of neutralizing antibodies against echoviruses. This suggests that the extent of infection and the antiviral immune response could influence the intensity of the humoral response against host antigens (Figure 4).
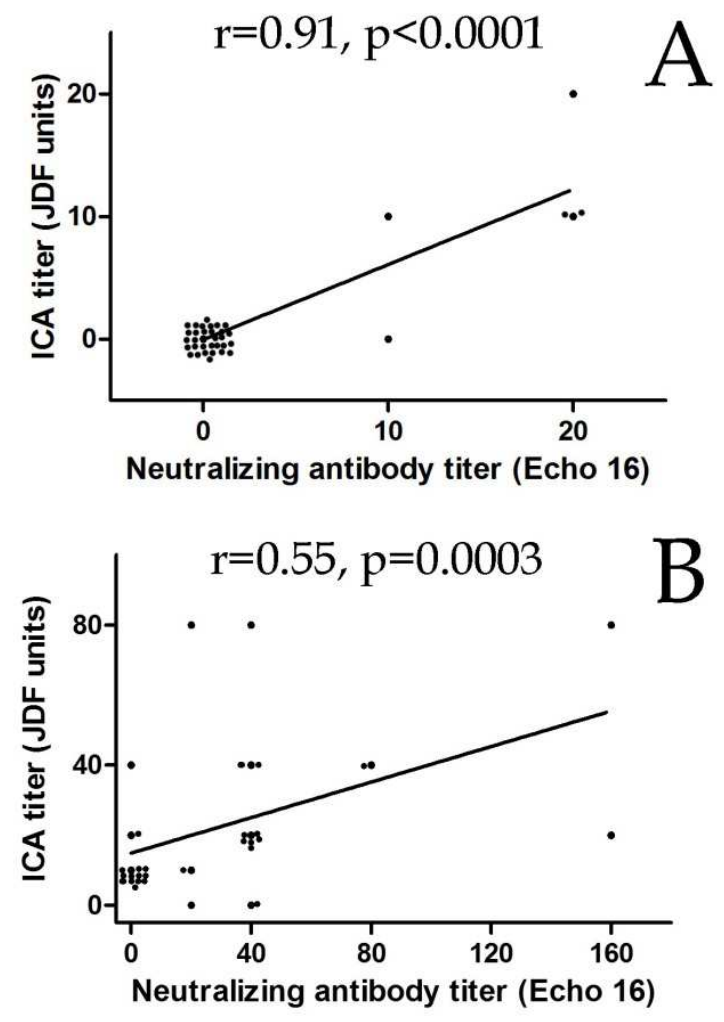

Fig. 4. Correlation between echovirus 16 neutralizing antibodies and ICA titers in sera of patients with aseptic meningitis in the acute (A) and convalescent (B) phase. 
We also evaluated the induction of T1D associated antibodies by HEVs in experimental animals. In particular, rabbits were used since HEVs do not replicate in their cells (Fields et al., 2007). This minimizes the possibility of generating of humoral responses as consequence of beta-cell damage and subsequent autoantigen release. Strikingly, seroconversion to GAD65 antibodies was restricted to HEVs of the B species. Antibodies recognizing GAD65 were absent after inoculation with HEVs of the A and the C species (Sarmiento et al., 2007b). Antibodies against IA2 or insulin were undetected. Although indirect, this evidence suggests that different HEVs of the species B could share epitopes with GAD65. Thus, molecular mimicry might explain the induction of T1D/associated autoantibodies during HEV epidemics.

Taken together, these results show the association between echovirus epidemics and the induction of T1D associated autoantibodies. Other studies have shown similar results (Frisk \& Tuvemo, 2004; Hiltunen et al., 1997; Lonnrot et al., 2000a; Moya-Suri et al., 2005; Oikarinen et al., 2011; Sadeharju et al., 2001; Salminen et al., 2003; Williams et al., 2006). Diabetogeneicity seems to be associated to HEVs of the B species although it is not restricted to one particular serotype or strain.

\section{Detection of HEVs at T1D onset and in prediabetic stages}

In 1999, neutralizing antibodies (NtAb) against different HEV types were measured in subjects with T1D at diagnosis and in controls matched for location, time of sampling, and age (Diaz-Horta et al., 2001). Both, patients and control subjects showed a high frequency of antibodies against a variety of HEV types (Table 1). Strikingly, the sole HEV serotype with $\mathrm{NtAbs}$ at higher frequency in cases vs. controls was echovirus 4 , i.e., the same serotype that caused the huge epidemic of aseptic meningitis during the year 1987. More recently, HEV RNA was searched for in blood of T1D children at the time of diagnosis, in their first degree relatives with or without ICA and in matched non diabetic controls (Sarmiento et al., 2007a). As shown in table 5, subjects at diagnosis and subjects with ICA showed higher frequencies of HEV RNA than their matched controls. These and other results (Andreoletti et al., 1997; Clements et al., 1995; Craig et al., 2003; Moya-Suri et al., 2005; Nairn et al., 1999; Yin et al., 2002) strongly suggest the link between HEV detection and the early stages of T1D.

\begin{tabular}{|c|c|c|c|}
\hline GROUP & $\mathrm{N}$ & HEV RNA+ $(\%)$ & P VALUE \\
\hline $\begin{array}{l}\text { T1D at clinical onset } \\
\text { Matched controls }\end{array}$ & $\begin{array}{l}34 \\
68\end{array}$ & $\begin{array}{l}9(26,5) \\
2(2,9)\end{array}$ & 0,0007 \\
\hline $\begin{array}{l}\text { First degree relatives of T1D patients (ICA+) } \\
\text { Matched controls }\end{array}$ & $\begin{array}{l}32 \\
64\end{array}$ & $\begin{array}{c}5(\mathbf{1 5}, \mathbf{6}) \\
0(0,0)\end{array}$ & 0,0033 \\
\hline $\begin{array}{l}\text { First degree relatives of T1D patients (ICA-) } \\
\text { Matched controls }\end{array}$ & $\begin{array}{l}62 \\
62\end{array}$ & $\begin{array}{l}1(1,6) \\
1(1,6)\end{array}$ & NS \\
\hline $\begin{array}{l}\text { First degree relatives of T1D patients (ICA+) } \\
\text { First degree relatives of T1D patients (ICA-) }\end{array}$ & $\begin{array}{l}32 \\
62\end{array}$ & $\begin{array}{c}5(\mathbf{1 5}, \mathbf{6}) \\
1(1,6)\end{array}$ & 0,0164 \\
\hline
\end{tabular}

Table 5. Frequency of enterovirus RNA in blood of subjects with T1D at clinical onset, their first degree relatives and controls matched for age, sex, date of collection and location (Sarmiento et al., 2007a). 1. p values were generated by the Fisher's exact test. NS = not significant. 
The frequency of HEV genome positivity appeared to vary according to the specimen (Schulte et al., 2010a). In newly diagnosed T1D patients, the highest frequency of HEV RNA is detected in peripheral blood mononuclear cells (PBMC) followed by plasma or serum. Cerebrospinal fluid (CSF) and stool samples are the specimens with the lowest percent of HEV genome detection. Since HEVs primarily replicated in the gut, a recent study addressed the question of whether these agents could be detected in the small intestine of patients at clinical onset of T1D (Oikarinen et al., 2008). By in situ hybridization or immunohistochemistry, up to $50 \%$ of T1D patients were positive for HEVs. This finding is apparently in contrast with studies on feces (Schulte et al., 2010a)(and unpublished results). It is however known that enterovirus isolation from feces is difficult when virus titer is low. This finding suggests that an asymptomatic/low level infection takes place in children during the initial stages of the disease. In this regard, it should be pointed out that the amount of HEV genomes in serum/ plasma and blood cells is extremely low and can only be evidence with highly sensitive methods (Sarmiento et al., 2007a; Schulte et al., 2010a). These findings indicate that small amounts of HEVs may derive from infected cells, e.g., cells of the islets of Langerhans islets or cell-debris (Schulte et al., 2010a; Schulte et al., 2010b). Though not yet demonstrated, virus low level persistence and/or low virus clearance are involved in T1D pathogenesis. In a recent study (Feuer et al., 2009), intracranial inoculation of BALB/C pups with Coxsackie B3 resulted in detection of the infecting virus at least for 10 days. At day 30, infectious virus was no longer present though viral RNA could be demonstrated by sensitive RT-PCR methods. Similar results have been reported for other target tissues, such as the myocardium (Kim et al., 2001; Klingel et al., 1992; Reetoo et al., 2000).

A recent meta-analysis by Craig and colleagues (Yeung et al., 2011) strongly indicates that HEVs (in terms of RNA detection) are unequivocally associated with T1D at the time of clinical presentation or at preclinical stages. Other data corroborate this association. Among them, the high frequency of IgM/IgG antibodies against HEVs (Banatvala et al., 1985; Elfaitouri et al., 2007; Helfand et al., 1995; King et al., 1983), the presence of interferon-a or dsRNA-dependent protein kinase $\mathrm{R}$ (indirect markers of virus infection) in serum and pancreas (Chehadeh et al., 2000; Foulis et al., 1987; Huang et al., 1995; Richardson et al., 2009), the demonstration of HEV capsid proteins in pancreatic islets (Dotta et al., 2007; Richardson et al., 2009; Tanaka et al., 2009).

\section{Conclusion}

The genetic background of a population influences the incidence of T1D. Although the HLA region confers the highest odds ratio, several other genes contribute to T1D susceptibility as suggested in our admixture study. The link between the IFIH1 polymorphism, and more recently the discovery of an entire network of interferon response genes driven by IRF7, corroborate the hypothesis that viruses have a role in T1D pathogenesis. These studies also evidence that HEV circulation is inversely proportional to T1D incidence. Upon exposure to a diabetogenic HEV, both the innate and adaptive immune response seem to have an influence on whether or not an individual will progress towards organ-specific autoimmunity and destruction of beta cells.

As indicated by studies of meningitis epidemics in Cuba, echoviruses - once thought to be harmless - appear to comprise a variety of pathogens causing slow and progressive disease. Current data indicate that different HEV types may be associated with the initial stages of 
T1D. Technical improvements are however needed to unequivocally prove this hypothesis and to pave the way to viral vaccines as a preventing measure against T1D.

\section{Aknowledgment}

$\mathrm{ODH}$ has been supported by a research fellowship of the University of Insubria, Varese (Italy). The support of CARIPLO Foundation (Milan, IT) and Gianni Valcavi, Attorney at law (Varese, IT) is gratefully acknowledged. We also thank the VIDIS Group (London, UK) and the Enterovirus Foundation (San Francisco, CA) for inspiration and assistance.

\section{References}

Agol, V. I. (2006). Molecular mechanisms of poliovirus variation and evolution. Curr Top Microbiol Immunol 299, 211-59

Akerblom, H. K., and Knip, M. (1998). Putative environmental factors in Type 1 diabetes. Diabetes Metab Rev 14(1), 31-67

Alegre, R., Moscoso, J., Martinez-Laso, J., Martin-Villa, M., Suarez, J., Moreno, A., SerranoVela, J. I., Vargas-Alarcon, G., Pacheco, R., and Arnaiz-Villena, A. (2007). HLA genes in Cubans and the detection of Amerindian alleles. Mol Immunol 44(9), 2426-35

Andreoletti, L., Hober, D., Hober-Vandenberghe, C., Belaich, S., Vantyghem, M. C., Lefebvre, J., and Wattre, P. (1997). Detection of coxsackie B virus RNA sequences in whole blood samples from adult patients at the onset of type I diabetes mellitus. $J$ Med Virol 52(2), 121-7

Aumeunier, A., Grela, F., Ramadan, A., Pham Van, L., Bardel, E., Gomez Alcala, A., Jeannin, P., Akira, S., Bach, J. F., and Thieblemont, N. (2010). Systemic Toll-like receptor stimulation suppresses experimental allergic asthma and autoimmune diabetes in NOD mice. PLoS One 5(7), e11484

Bach, J. F. (2002). The effect of infections on susceptibility to autoimmune and allergic diseases. N Engl J Med 347(12), 911-920

Bae, Y. S., Eun, H. M., and Yoon, J. W. (1989). Genomic differences between the diabetogenic and nondiabetogenic variants of encephalomyocarditis virus. Virology 170(1), 282-7

Bae, Y. S., and Yoon, J. W. (1993). Determination of diabetogenicity attributable to a single amino acid, Ala776, on the polyprotein of encephalomyocarditis virus. Diabetes 42(3), 435-43

Banatvala, J. E., Bryant, J., Schernthaner, G., Borkenstein, M., Schober, E., Brown, D., De Silva, L. M., Menser, M. A., and Silink, M. (1985). Coxsackie B, mumps, rubella, and cytomegalovirus specific IgM responses in patients with juvenile-onset insulindependent diabetes mellitus in Britain, Austria, and Australia. Lancet 1(8443), 1409-12

Barnett, A. H., Eff, C., Leslie, R. D., and Pyke, D. A. (1981). Diabetes in identical twins. A study of 200 pairs. Diabetologia 20(2), 87-93

Borchers, A. T., Uibo, R., and Gershwin, M. E. (2010). The geoepidemiology of type 1 diabetes. Autoimmun Rev 9(5), A355-65

Cabrera-Rode, E., Sarmiento, L., Molina, G., Perez, C., Arranz, C., Galvan, J. A., Prieto, M., Barrios, J., Palomera, R., Fonseca, M., Mas, P., Diaz-Diaz, O., and Diaz-Horta, O. (2005). Islet cell related antibodies and type 1 diabetes associated with echovirus 30 epidemic: a case report. J Med Virol 76(3), 373-7 
Cabrera-Rode, E., Sarmiento, L., Tiberti, C., Molina, G., Barrios, J., Hernandez, D., DiazHorta, O., and Di Mario, U. (2003). Type 1 diabetes islet associated antibodies in subjects infected by echovirus 16. Diabetologia 46(10), 1348-53

Chehadeh, W., Weill, J., Vantyghem, M. C., Alm, G., Lefebvre, J., Wattre, P., and Hober, D. (2000). Increased level of interferon-alpha in blood of patients with insulindependent diabetes mellitus: relationship with coxsackievirus B infection. J Infect Dis 181(6), 1929-39

Christen, U., Benke, D., Wolfe, T., Rodrigo, E., Rhode, A., Hughes, A. C., Oldstone, M. B., and von Herrath, M. G. (2004). Cure of prediabetic mice by viral infections involves lymphocyte recruitment along an IP-10 gradient. J Clin Invest 113(1), 74-84

Cintado, A., Companioni, O., Nazabal, M., Camacho, H., Ferrer, A., De Cossio, M. E., Marrero, A., Ale, M., Villarreal, A., Leal, L., Casalvilla, R., Benitez, J., Novoa, L., Diaz-Horta, O., and Duenas, M. (2009). Admixture estimates for the population of Havana City. Ann Hum Biol 36(3), 350-60

Clements, G. B., Galbraith, D. N., and Taylor, K. W. (1995). Coxsackie B virus infection and onset of childhood diabetes. Lancet 346(8969), 221-3

Collado-Mesa, F., Barcelo, A., Arheart, K. L., and Messiah, S. E. (2004). An ecological analysis of childhood-onset type 1 diabetes incidence and prevalence in Latin America. Rev Panam Salud Publica 15(6), 388-94

Concannon, P., Rich, S. S., and Nepom, G. T. (2009). Genetics of type 1A diabetes. N Engl J Med 360(16), 1646-54

Cooke, A. (2009). Review series on helminths, immune modulation and the hygiene hypothesis: how might infection modulate the onset of type 1 diabetes? Immunology 126(1), 12-7

Craig, M. E., Howard, N. J., Silink, M., and Rawlinson, W. D. (2003). Reduced frequency of HLA DRB1*03-DQB1*02 in children with type 1 diabetes associated with enterovirus RNA. J Infect Dis 187(10), 1562-70

Diaz-Horta, O., Bello, M., Cabrera-Rode, E., Suarez, J., Mas, P., Garcia, I., Abalos, I., Jofra, R., Molina, G., Diaz-Diaz, O., and Dimario, U. (2001). Echovirus 4 and type 1 diabetes mellitus. Autoimmunity 34(4), 275-81

Diaz-Horta, O., Cintado, A., Fernandez-De-Cossio, M. E., Nazabal, M., Ferrer, A., Roca, J., Camacho, H., Benitez, J., Ale, M., Villarreal, A., Molina, G., Vera, M., Cabrera-Rode, E., and Novoa, L. (2010). Relationship of type 1 diabetes to ancestral proportions and HLA DR/DQ alleles in a sample of the admixed Cuban population. Ann Hum Biol

Djikeng, A., Kuzmickas, R., Anderson, N. G., and Spiro, D. J. (2009). Metagenomic analysis of RNA viruses in a fresh water lake. PLoS One 4(9), e7264

Dorman, J. S., and Bunker, C. H. (2000). HLA-DQ locus of the human leukocyte antigen complex and type 1 diabetes mellitus: a HuGE review. Epidemiol Rev 22(2), 218-27

Dorman, J. S., LaPorte, R. E., Stone, R. A., and Trucco, M. (1990). Worldwide differences in the incidence of type I diabetes are associated with amino acid variation at position 57 of the HLA-DQ beta chain. Proc Natl Acad Sci U S A 87(19), 7370-4

Dotta, F., Censini, S., van Halteren, A. G., Marselli, L., Masini, M., Dionisi, S., Mosca, F., Boggi, U., Muda, A. O., Prato, S. D., Elliott, J. F., Covacci, A., Rappuoli, R., Roep, B. O., and Marchetti, P. (2007). Coxsackie B4 virus infection of beta cells and natural killer cell insulitis in recent-onset type 1 diabetic patients. Proc Natl Acad Sci U S A 104(12), 5115-20 
Elfaitouri, A., Berg, A. K., Frisk, G., Yin, H., Tuvemo, T., and Blomberg, J. (2007). Recent enterovirus infection in type 1 diabetes: evidence with a novel IgM method. J Med Virol 79(12), 1861-7

Feillet, H., and Bach, J. F. (2004). On the mechanisms of the protective effect of infections on type 1 diabetes. Clin Dev Immunol 11(3-4), 191-4

Fernando, M. M., Stevens, C. R., Walsh, E. C., De Jager, P. L., Goyette, P., Plenge, R. M., Vyse, T. J., and Rioux, J. D. (2008). Defining the role of the MHC in autoimmunity: a review and pooled analysis. PLoS Genet 4(4), e1000024

Feuer, R., Ruller, C. M., An, N., Tabor-Godwin, J. M., Rhoades, R. E., Maciejewski, S., Pagarigan, R. R., Cornell, C. T., Crocker, S. J., Kiosses, W. B., Pham-Mitchell, N., Campbell, I. L., and Whitton, J. L. (2009). Viral persistence and chronic immunopathology in the adult central nervous system following Coxsackievirus infection during the neonatal period. J Virol 83(18), 9356-69

Fields, B. N., Knipe, D. M., and Howley, P. M. (2007). "Fields' virology." 5th ed. / editors-inchief, David M. Knipe, Peter M. Howley ; associate editors, Diane E. Griffin ... [et al.]. ed. Wolters Kluwer/Lippincott Williams \& Wilkins, Philadelphia, Pa. ; London.

Foulis, A. K., Farquharson, M. A., and Meager, A. (1987). Immunoreactive alpha-interferon in insulin-secreting beta cells in type 1 diabetes mellitus. Lancet 2(8573), 1423-7

Foxman, E. F., and Iwasaki, A. (2011). Genome-virome interactions: examining the role of common viral infections in complex disease. Nat Rev Microbiol 9(4), 254-64

Frisk, G., and Tuvemo, T. (2004). Enterovirus infections with beta-cell tropic strains are frequent in siblings of children diagnosed with type 1 diabetes children and in association with elevated levels of GAD65 antibodies. J Med Virol 73(3), 450-9

Heinig, M., Petretto, E., Wallace, C., Bottolo, L., Rotival, M., Lu, H., Li, Y., Sarwar, R., Langley, S. R., Bauerfeind, A., Hummel, O., Lee, Y. A., Paskas, S., Rintisch, C., Saar, K., Cooper, J., Buchan, R., Gray, E. E., Cyster, J. G., Erdmann, J., Hengstenberg, C., Maouche, S., Ouwehand, W. H., Rice, C. M., Samani, N. J., Schunkert, H., Goodall, A. H., Schulz, H., Roider, H. G., Vingron, M., Blankenberg, S., Munzel, T., Zeller, T., Szymczak, S., Ziegler, A., Tiret, L., Smyth, D. J., Pravenec, M., Aitman, T. J., Cambien, F., Clayton, D., Todd, J. A., Hubner, N., and Cook, S. A. (2010). A trans-acting locus regulates an anti-viral expression network and type 1 diabetes risk. Nature 467(7314), 460-4

Helfand, R. F., Gary, H. E., Jr., Freeman, C. Y., Anderson, L. J., and Pallansch, M. A. (1995). Serologic evidence of an association between enteroviruses and the onset of type 1 diabetes mellitus. Pittsburgh Diabetes Research Group. J Infect Dis 172(5), 1206-11

Hemminki, K., Li, X., Sundquist, K., and Sundquist, J. (2010). Familial risks for type 2 diabetes in Sweden. Diabetes Care 33(2), 293-7

Herr, M., Dudbridge, F., Zavattari, P., Cucca, F., Guja, C., March, R., Campbell, R. D., Barnett, A. H., Bain, S. C., Todd, J. A., and Koeleman, B. P. (2000). Evaluation of fine mapping strategies for a multifactorial disease locus: systematic linkage and association analysis of IDDM1 in the HLA region on chromosome 6p21. Hum Mol Genet 9(9), 1291-301

Hiltunen, M., Hyoty, H., Knip, M., Ilonen, J., Reijonen, H., Vahasalo, P., Roivainen, M., Lonnrot, M., Leinikki, P., Hovi, T., and Akerblom, H. K. (1997). Islet cell antibody seroconversion in children is temporally associated with enterovirus infections. Childhood Diabetes in Finland (DiMe) Study Group. J Infect Dis 175(3), 554-60

Hirai, H., Miura, J., Hu, Y., Larsson, H., Larsson, K., Lernmark, A., Ivarsson, S. A., Wu, T., Kingman, A., Tzioufas, A. G., and Notkins, A. L. (2008). Selective screening of 
secretory vesicle-associated proteins for autoantigens in type 1 diabetes: VAMP2 and NPY are new minor autoantigens. Clin Immunol 127(3), 366-74

Hoggart, C. J., Parra, E. J., Shriver, M. D., Bonilla, C., Kittles, R. A., Clayton, D. G., and McKeigue, P. M. (2003). Control of confounding of genetic associations in stratified populations. Am J Hum Genet 72(6), 1492-1504

Huang, X., Yuang, J., Goddard, A., Foulis, A., James, R. F., Lernmark, A., Pujol-Borrell, R., Rabinovitch, A., Somoza, N., and Stewart, T. A. (1995). Interferon expression in the pancreases of patients with type I diabetes. Diabetes 44(6), 658-64

Hyoty, H., and Taylor, K. W. (2002). The role of viruses in human diabetes. Diabetologia 45(10), 1353-61

Hyypia, T., Hovi, T., Knowles, N. J., and Stanway, G. (1997). Classification of enteroviruses based on molecular and biological properties. J Gen Virol 78 ( Pt 1), 1-11

Ikegami, H., Noso, S., Babaya, N., Hiromine, Y., and Kawabata, Y. (2008). Genetic Basis of Type 1 Diabetes: Similarities and Differences between East and West. Rev Diabet Stud 5(2), 64-72

Jun, H. S., and Yoon, J. W. (2003). A new look at viruses in type 1 diabetes. Diabetes Metab Res Rev 19(1), 8-31

Karvonen, M., Viik-Kajander, M., Moltchanova, E., Libman, I., LaPorte, R., and Tuomilehto, J. (2000). Incidence of childhood type 1 diabetes worldwide. Diabetes Mondiale (DiaMond) Project Group. Diabetes Care 23(10), 1516-26

Khetsuriani, N., Lamonte-Fowlkes, A., Oberst, S., and Pallansch, M. A. (2006). Enterovirus surveillance--United States, 1970-2005. MMWR Surveill Summ 55(8), 1-20

Kim, K. S., Hufnagel, G., Chapman, N. M., and Tracy, S. (2001). The group B coxsackieviruses and myocarditis. Rev Med Virol 11(6), 355-68

King, M. L., Shaikh, A., Bidwell, D., Voller, A., and Banatvala, J. E. (1983). Coxsackie-Bvirus-specific IgM responses in children with insulin-dependent (juvenile-onset; type I) diabetes mellitus. Lancet 1(8339), 1397-9

Klingel, K., Hohenadl, C., Canu, A., Albrecht, M., Seemann, M., Mall, G., and Kandolf, R. (1992). Ongoing enterovirus-induced myocarditis is associated with persistent heart muscle infection: quantitative analysis of virus replication, tissue damage, and inflammation. Proc Natl Acad Sci U S A 89(1), 314-8

Knip, M., Veijola, R., Virtanen, S. M., Hyoty, H., Vaarala, O., and Akerblom, H. K. (2005). Environmental triggers and determinants of type 1 diabetes. Diabetes 54 Suppl 2, S125-36

Liston, A. (2010). How many genes in type 1 diabetes? International Diabetes Monitor 22(2), 90-93

Lonnrot, M., Korpela, K., Knip, M., Ilonen, J., Simell, O., Korhonen, S., Savola, K., Muona, P., Simell, T., Koskela, P., and Hyoty, H. (2000a). Enterovirus infection as a risk factor for beta-cell autoimmunity in a prospectively observed birth cohort: the Finnish Diabetes Prediction and Prevention Study. Diabetes 49(8), 1314-8

Lonnrot, M., Salminen, K., Knip, M., Savola, K., Kulmala, P., Leinikki, P., Hyypia, T., Akerblom, H. K., and Hyoty, H. (2000b). Enterovirus RNA in serum is a risk factor for beta-cell autoimmunity and clinical type 1 diabetes: a prospective study. Childhood Diabetes in Finland (DiMe) Study Group. J Med Virol 61(2), 214-20

Martins, T. C., and Aguas, A. P. (1996). Changes in B and T lymphocytes associated with mycobacteria-induced protection of NOD mice from diabetes. J Autoimmun 9(4), 501-7 
Matsuzaki, T., Nagata, Y., Kado, S., Uchida, K., Kato, I., Hashimoto, S., and Yokokura, T. (1997). Prevention of onset in an insulin-dependent diabetes mellitus model, NOD mice, by oral feeding of Lactobacillus casei. APMIS 105(8), 643-9

McInerney, M. F., Pek, S. B., and Thomas, D. W. (1991). Prevention of insulitis and diabetes onset by treatment with complete Freund's adjuvant in NOD mice. Diabetes 40(6), 715-25

Morel, P. A., Dorman, J. S., Todd, J. A., McDevitt, H. O., and Trucco, M. (1988). Aspartic acid at position 57 of the HLA-DQ beta chain protects against type I diabetes: a family study. Proc Natl Acad Sci U S A 85(21), 8111-5

Moya-Suri, V., Schlosser, M., Zimmermann, K., Rjasanowski, I., Gurtler, L., and Mentel, R. (2005). Enterovirus RNA sequences in sera of schoolchildren in the general population and their association with type 1-diabetes-associated autoantibodies. $J$ Med Microbiol 54(Pt 9), 879-83

Nairn, C., Galbraith, D. N., Taylor, K. W., and Clements, G. B. (1999). Enterovirus variants in the serum of children at the onset of Type 1 diabetes mellitus. Diabet Med 16(6), 509-13

Nakayama, M., Abiru, N., Moriyama, H., Babaya, N., Liu, E., Miao, D., Yu, L., Wegmann, D. R., Hutton, J. C., Elliott, J. F., and Eisenbarth, G. S. (2005). Prime role for an insulin epitope in the development of type 1 diabetes in NOD mice. Nature 435(7039), 220-3

Nejentsev, S., Walker, N., Riches, D., Egholm, M., and Todd, J. A. (2009). Rare variants of IFIH1, a gene implicated in antiviral responses, protect against type 1 diabetes. Science 324(5925), 387-9

Nomaguchi, H., Yogi, Y., Kawatsu, K., Okamura, H., Ozawa, Y., and Kasatani, T. (2002). Prevention of diabetes in non-obese diabetic mice by a single immunization with Mycobacterium leprae. Nihon Hansenbyo Gakkai Zasshi 71(1), 31-8

Notkins, A. L. (2007). New predictors of disease. Molecules called predictive autoantibodies appear in the blood years before people show symptoms of various disorders. Tests that detected these molecules could warn of the need to take preventive action. Sci Am 296(3), 72-9

Notkins, A. L., and Yoon, J. W. (1982). Virus-induced diabetes in mice prevented by a live attenuated vaccine. $N$ Engl J Med 306(8), 486

Oikarinen, M., Tauriainen, S., Honkanen, T., Oikarinen, S., Vuori, K., Kaukinen, K., Rantala, I., Maki, M., and Hyoty, H. (2008). Detection of enteroviruses in the intestine of type 1 diabetic patients. Clin Exp Immunol 151(1), 71-5

Oikarinen, S., Martiskainen, M., Tauriainen, S., Huhtala, H., Ilonen, J., Veijola, R., Simell, O., Knip, M., and Hyoty, H. (2011). Enterovirus RNA in blood is linked to the development of type 1 diabetes. Diabetes 60(1), 276-9

Otonkoski, T., Roivainen, M., Vaarala, O., Dinesen, B., Leipala, J. A., Hovi, T., and Knip, M. (2000). Neonatal Type I diabetes associated with maternal echovirus 6 infection: a case report. Diabetologia 43(10), 1235-8

Parry, C. S., and Brooks, B. R. (2008). A new model defines the minimal set of polymorphism in HLA-DQ and -DR that determines susceptibility and resistance to autoimmune diabetes. Biol Direct 3, 42

Petrovsky, N. (2010). Immunomodulation with microbial vaccines to prevent type 1 diabetes mellitus. Nat Rev Endocrinol 6(3), 131-8

Redondo, M. J., Rewers, M., Yu, L., Garg, S., Pilcher, C. C., Elliott, R. B., and Eisenbarth, G. S. (1999). Genetic determination of islet cell autoimmunity in monozygotic twin, dizygotic twin, and non-twin siblings of patients with type 1 diabetes: prospective twin study. BMJ 318(7185), 698-702 
Redondo, M. J., Yu, L., Hawa, M., Mackenzie, T., Pyke, D. A., Eisenbarth, G. S., and Leslie, R. D. (2001). Heterogeneity of type I diabetes: analysis of monozygotic twins in Great Britain and the United States. Diabetologia 44(3), 354-62

Reetoo, K. N., Osman, S. A., Illavia, S. J., Cameron-Wilson, C. L., Banatvala, J. E., and Muir, P. (2000). Quantitative analysis of viral RNA kinetics in coxsackievirus B3-induced murine myocarditis: biphasic pattern of clearance following acute infection, with persistence of residual viral RNA throughout and beyond the inflammatory phase of disease. J Gen Virol 81(Pt 11), 2755-62

Richardson, S. J., Willcox, A., Bone, A. J., Foulis, A. K., and Morgan, N. G. (2009). The prevalence of enteroviral capsid protein vp1 immunostaining in pancreatic islets in human type 1 diabetes. Diabetologia 52(6), 1143-51

Roivainen, M., Ylipaasto, P., Savolainen, C., Galama, J., Hovi, T., and Otonkoski, T. (2002). Functional impairment and killing of human beta cells by enteroviruses: the capacity is shared by a wide range of serotypes, but the extent is a characteristic of individual virus strains. Diabetologia 45(5), 693-702

Sadeharju, K., Lonnrot, M., Kimpimaki, T., Savola, K., Erkkila, S., Kalliokoski, T., Savolainen, P., Koskela, P., Ilonen, J., Simell, O., Knip, M., and Hyoty, H. (2001). Enterovirus antibody levels during the first two years of life in prediabetic autoantibodypositive children. Diabetologia 44(7), 818-23

Salminen, K., Sadeharju, K., Lonnrot, M., Vahasalo, P., Kupila, A., Korhonen, S., Ilonen, J., Simell, O., Knip, M., and Hyoty, H. (2003). Enterovirus infections are associated with the induction of beta-cell autoimmunity in a prospective birth cohort study. $J$ Med Virol 69(1), 91-8

Sarmiento, L., Cabrera-Rode, E., Lekuleni, L., Cuba, I., Molina, G., Fonseca, M., Heng-Hung, L., Borroto, A. D., Gonzalez, P., Mas-Lago, P., and Diaz-Horta, O. (2007a). Occurrence of enterovirus RNA in serum of children with newly diagnosed type 1 diabetes and islet cell autoantibody-positive subjects in a population with a low incidence of type 1 diabetes. Autoimmunity 40(7), 540-5

Sarmiento, L., Cabrera-Rode, E., Mas-Lago, P., and Diaz-Horta, O. (2007b). Antibodies to human glutamic acid decarboxylase in sera from enterovirus-immunized rabbit. Autoimmunity 40(7), 546-7

Sarmiento, L., Mas, P., Goyenechea, A., Palomera, R., Morier, L., Capo, V., Quintana, I., and Santin, M. (2001). First epidemic of echovirus 16 meningitis in Cuba. Emerg Infect Dis 7(5), 887-9

Savolainen-Kopra, C., and Blomqvist, S. (2010). Mechanisms of genetic variation in polioviruses. Rev Med Virol 20(6), 358-71

Schulte, B. M., Bakkers, J., Lanke, K. H., Melchers, W. J., Westerlaken, C., Allebes, W., Aanstoot, H. J., Bruining, G. J., Adema, G. J., Van Kuppeveld, F. J., and Galama, J. M. (2010a). Detection of enterovirus RNA in peripheral blood mononuclear cells of type 1 diabetic patients beyond the stage of acute infection. Viral Immunol 23(1), 99-104

Schulte, B. M., Kramer, M., Ansems, M., Lanke, K. H., van Doremalen, N., Piganelli, J. D., Bottino, R., Trucco, M., Galama, J. M., Adema, G. J., and van Kuppeveld, F. J. (2010b). Phagocytosis of enterovirus-infected pancreatic beta-cells triggers innate immune responses in human dendritic cells. Diabetes 59(5), 1182-91

Shapiro, A. M., Ricordi, C., Hering, B. J., Auchincloss, H., Lindblad, R., Robertson, R. P., Secchi, A., Brendel, M. D., Berney, T., Brennan, D. C., Cagliero, E., Alejandro, R., Ryan, E. A., DiMercurio, B., Morel, P., Polonsky, K. S., Reems, J. A., Bretzel, R. G., Bertuzzi, F., Froud, T., Kandaswamy, R., Sutherland, D. E., Eisenbarth, G., Segal, 
M., Preiksaitis, J., Korbutt, G. S., Barton, F. B., Viviano, L., Seyfert-Margolis, V., Bluestone, J., and Lakey, J. R. (2006). International trial of the Edmonton protocol for islet transplantation. N Engl J Med 355(13), 1318-30

She, J. X. (1996). Susceptibility to type I diabetes: HLA-DQ and DR revisited. Immunol Today 17(7), 323-9

Simmonds, P. (2006). Recombination and selection in the evolution of picornaviruses and other Mammalian positive-stranded RNA viruses. J Virol 80(22), 11124-40

Szopa, T. M., Ward, T., and Taylor, K. W. (1992). Disturbance of mouse pancreatic beta-cell function following echo 4 virus infection. Biochem Soc Trans 20(4), $315 \mathrm{~S}$

Tanaka, S., Nishida, Y., Aida, K., Maruyama, T., Shimada, A., Suzuki, M., Shimura, H., Takizawa, S., Takahashi, M., Akiyama, D., Arai-Yamashita, S., Furuya, F., Kawaguchi, A., Kaneshige, M., Katoh, R., Endo, T., and Kobayashi, T. (2009). Enterovirus infection, CXC chemokine ligand 10 (CXCL10), and CXCR3 circuit: a mechanism of accelerated beta-cell failure in fulminant type 1 diabetes. Diabetes 58(10), 2285-91

Uriarte, A., Cabrera-Rode, E., Ventura, R., and Vargas, J. (1987). Islet cell antibodies and Echo 4 virus infection. Diabetologia 30(A), 590

Vaysburd, M., Lock, C., and McDevitt, H. (1995). Prevention of insulin-dependent diabetes mellitus in nonobese diabetic mice by immunogenic but not by tolerated peptides. $J$ Exp Med 182(3), 897-902

Viskari, H., Ludvigsson, J., Uibo, R., Salur, L., Marciulionyte, D., Hermann, R., Soltesz, G., Fuchtenbusch, M., Ziegler, A. G., Kondrashova, A., Romanov, A., Kaplan, B., Laron, Z., Koskela, P., Vesikari, T., Huhtala, H., Knip, M., and Hyoty, H. (2005). Relationship between the incidence of type 1 diabetes and maternal enterovirus antibodies: time trends and geographical variation. Diabetologia 48(7), 1280-7

Voltarelli, J. C., Couri, C. E., Stracieri, A. B., Oliveira, M. C., Moraes, D. A., Pieroni, F., Coutinho, M., Malmegrim, K. C., Foss-Freitas, M. C., Simoes, B. P., Foss, M. C., Squiers, E., and Burt, R. K. (2007). Autologous nonmyeloablative hematopoietic stem cell transplantation in newly diagnosed type 1 diabetes mellitus. JAMA 297(14), 1568-76

von Herrath, M. (2009). Can we learn from viruses how to prevent type 1 diabetes?: the role of viral infections in the pathogenesis of type 1 diabetes and the development of novel combination therapies. Diabetes 58(1), 2-11

Vreugdenhil, G. R., Schloot, N. C., Hoorens, A., Rongen, C., Pipeleers, D. G., Melchers, W. J., Roep, B. O., and Galama, J. M. (2000). Acute onset of type I diabetes mellitus after severe echovirus 9 infection: putative pathogenic pathways. Clin Infect Dis 31(4), 1025-31

Williams, C. H., Oikarinen, S., Tauriainen, S., Salminen, K., Hyoty, H., and Stanway, G. (2006). Molecular analysis of an echovirus 3 strain isolated from an individual concurrently with appearance of islet cell and IA-2 autoantibodies. J Clin Microbiol 44(2), 441-8

Yeung, W. C., Rawlinson, W. D., and Craig, M. E. (2011). Enterovirus infection and type 1 diabetes mellitus: systematic review and meta-analysis of observational molecular studies. BMJ 342, d35

Yin, H., Berg, A. K., Tuvemo, T., and Frisk, G. (2002). Enterovirus RNA is found in peripheral blood mononuclear cells in a majority of type 1 diabetic children at onset. Diabetes 51(6), 1964-71 


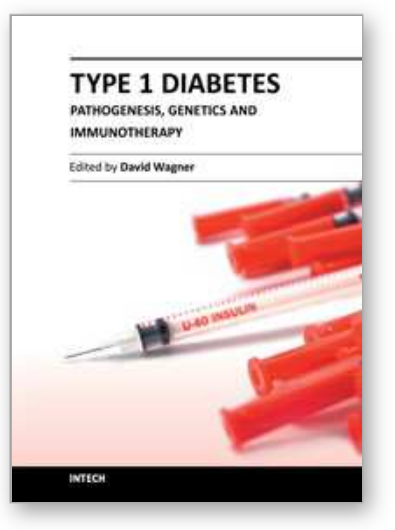

\author{
Type 1 Diabetes - Pathogenesis, Genetics and Immunotherapy \\ Edited by Prof. David Wagner
}

ISBN 978-953-307-362-0

Hard cover, 660 pages

Publisher InTech

Published online 25, November, 2011

Published in print edition November, 2011

This book is a compilation of reviews about the pathogenesis of Type 1 Diabetes. T1D is a classic autoimmune disease. Genetic factors are clearly determinant but cannot explain the rapid, even overwhelming expanse of this disease. Understanding etiology and pathogenesis of this disease is essential. A number of experts in the field have covered a range of topics for consideration that are applicable to researcher and clinician alike. This book provides apt descriptions of cutting edge technologies and applications in the ever going search for treatments and cure for diabetes. Areas including $T$ cell development, innate immune responses, imaging of pancreata, potential viral initiators, etc. are considered.

\title{
How to reference
}

In order to correctly reference this scholarly work, feel free to copy and paste the following:

Oscar Diaz-Horta, Luis Sarmiento, Andreina Baj, Eduardo Cabrera-Rode and Antonio Toniolo (2011).

Echovirus Epidemics, Autoimmunity, and Type 1 Diabetes, Type 1 Diabetes - Pathogenesis, Genetics and Immunotherapy, Prof. David Wagner (Ed.), ISBN: 978-953-307-362-0, InTech, Available from:

http://www.intechopen.com/books/type-1-diabetes-pathogenesis-genetics-and-immunotherapy/echovirusepidemics-autoimmunity-and-type-1-diabetes

\section{INTECH}

open science | open minds

\section{InTech Europe}

University Campus STeP Ri

Slavka Krautzeka 83/A

51000 Rijeka, Croatia

Phone: +385 (51) 770447

Fax: +385 (51) 686166

www.intechopen.com

\section{InTech China}

Unit 405, Office Block, Hotel Equatorial Shanghai

No.65, Yan An Road (West), Shanghai, 200040, China

中国上海市延安西路65号上海国际贵都大饭店办公楼405单元

Phone: +86-21-62489820

Fax: $+86-21-62489821$ 
(C) 2011 The Author(s). Licensee IntechOpen. This is an open access article distributed under the terms of the Creative Commons Attribution 3.0 License, which permits unrestricted use, distribution, and reproduction in any medium, provided the original work is properly cited. 